\title{
Visionary Leadership in Madrasah's Head Education Quality Development (Study at Madrasah Ibtidaiyah Al-Abrar, Makassar City)
}

\author{
Mulyadi \\ Pascasarjana Universitas Islam Makassar \\ Email: mulyadimpd212@gmail.com
}

\begin{abstract}
The goals of this study are to; 1) analyze Madrasah principals' innovative leadership strategies in improving the quality of education at Madrasah Ibtidaiyah Al-Abrar Makassar City and 2) assess the efficacy of Madrasah principals' visionary leadership in developing the quality of education at Madrasah Ibtidaiyah Al-Abrar Makassar City. This type of research is descriptive qualitative research. Sources of research data are the principal, the head of the foundation and the Ibtidaiyah Al-Abrar teachers in Makassar City. Data collection techniques are carried out through observation, interviews, and documentation. The approach taken is phenomenological. The data analysis of this study used qualitative methods, with data analysis carried out by steps, data reduction, data display, and 3) data verification. The data validity test is past due to source triangulation to test the validity of data. The results showed that the visionary leadership strategy of the headmaster of madrasah in developing the quality of education of Madrasah Ibtidaiyah AlAbrar in Makassar City, includes a) Looking to the future seen in the vision initiated, b) Able to formulate a clear vision, seen in the vision elaboration that refers to the vision madrasah, c) Able to change the vision into action, seen in the formulation of the mission and the exemplary attitude of the principal of the madrasah performance.
\end{abstract}

Keywords: Visionary Leadership, Education Quality, Madrasah's Head

Abstrak: Penelitian ini bertujuan untuk: 1) mengkaji strategi kepemimpinan visioner kepala madrasah dalam mengembangkan mutu pendidikan Madrasah Ibtidaiyah Al-Abrar Kota Makassar, dan 2) mengetahui efektifitas kepemimpinan visioner kepala madrasah dalam pengembangan mutu pendidikan Madrasah Ibtidaiyah Al-Abrar Kota Makassar. Jenis penelitian ini adalah penelitian kualitatif dekriptif. Sumber data penelitian adalah kepala sekolah, ketua yayasan dan guru Ibtidaiyah Al-Abrar Kota Makassar. Teknik pengumpulan data dilakukan melalui observasi, wawancara, dan dokumentasi. Pendekatan yang dilakukan adalah fenomenologis. Analisis data penelitian ini menggunakan metode kualitatif, dengan analisis data yang dilakukan dengan langkahlangkah, data reduction (reduksi data), display (penyajian) data, dan 3) verifikasi data. Uji keabsahan data menunggakan triangulasi sumber untuk pengujian keabsahan data penelitian ini. Hasil penelitian menunjukkan bahwa strategi kepemimpinan visioner kepala madrasah dalam mengembangkan mutu pendidikan Madrasah Ibtidaiyah Al-Abrar Kota Makassar, meliputi a) Berwawasan ke masa depan tampak pada visi yang digagas, b) Mampu merumuskan visi yang jelas, tampak pada penjabaran visi yang mengacu pada visi madrasah, 
c) Mampu mengubah visi ke dalam aksi, tampak pada rumusan misi dan sikap keteladanan kinerja kepala madrasah.

Kata-kata kunci: Kepemimpinan Visioner, Mutu Pendidikan, Kepala Madrasah

\section{Introduction}

One of the most severe problems in education in this country today is the low quality of education. The quality of education will always attract attention because the future of the nation depends on the quality of education, especially entering the era of globalization. The complexity of the school as an educational institution is growing along with the level of development of demands from parents, students and the wider community. In general, Madrasahs in Indonesia are still of inferior quality $^{1}$. The quality is lower than other schools of the same level, but it is still regarded as the community's number two school on different levels.

There are numerous issues with Islamic education institutions in Indonesia, including a lack of qualified teachers, poor teacher performance and welfare, traditional learning processes, limited education budgets, and poor human resource management. The output of graduates and the Life Skills result is not compatible with what is needed, and education is still not based on community and environment ${ }^{2}$. These issues are a challenge for the world of school education, and urgent solutions are needed. The main factor that encourages the importance of improving the quality of Madrasah's management is improving and improving the quality of education so that efforts to improve learning and teaching require better attention, primarily through improving the quality of management.

The Madrasah's principal must play a more strategic and professional role in improving learning and teaching efficiency. He is a learning leader and an overall leader, with responsibilities that include planning, career development, teamwork, and assessment in a school setting. His leadership style has a great deal of influence and also affects educational development ${ }^{3}$.

Leadership is an action taken by an individual or group to coordinate and give direction to other individuals or groups who are members of a particular container to achieve predetermined goals ${ }^{4}$. In the Qur'an, leadership is referred to as the caliph, as seen in the letter Al-Baqarah / 2:30.

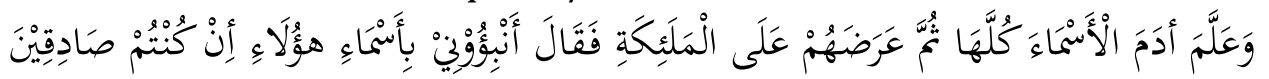

$$
\text { ( البقرة (31/2 ) }
$$

Translation: Remember when your Lord said to the angels: Verily I want to make a caliph on earth." they said: "Why do you want to make (caliph) on earth a person who will cause damage to him and shed blood, even though

1 Ahmad Tafsir, Ilmu Pendidikan Islam dalam Prespektif Isalam Bandung: PT. Remaja Rosdakarya, 1991, p. 107.

2 Nur Ahmad, "Problem Pengelolah Madrasah Aliyah dan Solusinya," Islamica, Volume 18, No. 2, 2010, p. 339.

${ }^{3}$ Depdiknas, Panduan Manajemen Pendidikan, Jakarta: 2000, p. 11.

4 Sudarwan Danim, Visi Baru Manajemen Sekolah Dari Unit Birokrasi ke Lembaga Akademik, Jakarta: Bumi Aksara, 2008, p. 204. 
We Always Praise by praising You and purifying You?" God says: Verily I know what you do not know ${ }^{5}$.

This verse explains the commandment to give room to others in all matters. This verse also does not explicitly state that Allah SWT will exalt a knowledgeable person. However, affirming that they have higher degrees than simply believing, there is no mention of the word exalting it as a sign that the knowledge they have plays a significant role in the height of the degrees they get, not the result of factors outside of that knowledge6.

Leadership is an effort to influence individual or group activities to achieve organizational goals intentionally. In an organization, leadership becomes an essential part of the effort to create the performance of all resources to achieve predetermined goals. Sergivanni classifies leadership abilities as cited by Owen as conceptual, humanistic, and technical. Meanwhile, Owen himself mentioned two types of principal leadership, namely symbolic leadership and cultural leadership. Furthermore, Suyanto saw that school/madrasah principals must have transformative leadership to optimize the role of all school elements 7 .

Guthrie and Reed consider the complexity of the school, required Visionarytransformative strategic leadership. According to Mantja, it should be able to create an excellent organizational climate so that all components of the school can independently establish themselves together to achieve organizational goals and objectives $^{8}$.

Apart from this approach, but what is more important is that the principal's job is an essential part of the education process in schools. The principal is responsible for hiring and supervising all teachers and other school personnel because the principal is the person who is responsible for evaluating all teachers, especially teachers who are just teaching ${ }^{9}$.

Regarding the leadership of the school/madrasah principal, Suparji argues that schools as agents of change in schools have an active role in improving the quality of education. To improve the quality of school management, the principal as a leader must have good leadership abilities. The duties of school principals are often formulated by EMASLIM, namely: educator (education), manager, administrator, supervisor, leader (leader), innovator (creator) and motivator (driver) 10. Therefore, good leadership is a principal who can manage all educational resources to achieve educational goals. As the leader of learning and human resources, the principal should create an excellent organizational climate so that the school's potential is dense in acting together to achieve organizational

${ }^{5}$ Departemen Agama Republik Indonesia, Al Qur'an dan Terjemahannya, (Semarang: PT Toha Putra, 1998), p. 13.

${ }^{6}$ M. Quraish Shihab, Tafsir Al-Mishbah; Pesan, Kesan Dan Keserasian Al-Qur'an, (Jakarta: Lentera Hati, 2002), p. 79.

${ }^{7}$ Rasmianto, "Kepemimpinan Kepala Sekolah Berwawasan Visioner-Tranformatif", Pendidikan dan Kebudayaan, eL-Harakah, No. 59, (Malang: UIN Malang, Maret-Juni 2003), p. 15.

${ }^{8}$ Ibid, p.15

${ }^{9}$ Gene E, Lindah F, Donna M, Mengajar Dengan Menyenangkan (Jakarta: Indeks, 2008), p.141.

${ }^{10}$ Suparji, "Profesionalisme Guru. "Jurnal Pendidikan dan Kebudayaan, Edukasi, No.14 (Sumenep: Dispen, 2010), p. 25. 
goals and objectives. That is an alternative leadership called visionarytransformative leadership 11 .

Leadership that is relevant to the demands of school-based management and desirable for improving the quality of education is visionary leadership, which is leadership whose primary work is focused on engineering a challenging future. Then become a superior change agent and determine the organization's direction that understands priorities, become a professional trainer, and can guide other personnel towards the expected work professionalism ${ }^{12}$.

The importance of visionary leadership applies in all schools, including Madrasah Ibtidaiyah Al-Abrar, Makassar City. In his position as the highest leader in the madrasah, the principal of Madrasah Al-Abrar strives to raise awareness among all madrasah staff. The success and decline of an educational institution are not solely dependent on the role of the madrasah's leader but rather occurs when all madrasah personnel participate.

The aim of resigning an educational institution is not only based on the role of the head of the Madrasah as the head of the institution, but this change occurs when all madrasah personnel play an active role in the implementation of the education process within the Madrasah so that the purpose of establishing the school can develop ideally in accordance with the objectives expected by the institution itself. Therefore, to produce a conducive teaching and learning process and a superior school, what is needed is the leadership of a madrasa principal who is able to play his leadership and improve the professionalism of his teachers. Because the teacher is a transformational medium for all the knowledge students need. In addition, the role of the teacher is needed to prepare students to continue their education at a higher level of education.

\section{Leadership}

The ability of a leader to develop, formulate, communicate/socialize/transform, and as a result of social interaction between organizational members and stakeholders who are perceived to be the organization's potential goals that must be accomplished or realized by the commitment of all staff, is known as visionary leadership ${ }^{13}$.

Visionary leadership is a leader's ability to create, formulate, socialize or transform, and implement ideal thoughts that come from him or as a result of social interactions among organizational members and stakeholders who believe in future organizational ideals that must be achieved or realized through the commitment of all personnel. That is an alternative to leadership which is called visionary-transformative leadership.

Leadership is an approach to leadership that emphasizes emotional skills. Human resources are driven by transformational leadership to an increased sensitivity of coaching and organizational growth, shared development of a vision,

\footnotetext{
${ }^{11}$ Rasmianto, op.cit, p. 22.

${ }^{12}$ Aan Komariah dan Cepi Triatna, Visionary Leadership Menuju Sekolah Efektif, (Jakarta: Bumi Aksara, 2005), pp. 81-82

${ }^{13}$ Ibid, pp. 81-82
} 
leadership authority distribution, and a school organizational culture, which is a must in school restructuring schemes ${ }^{14}$.

Visionary leadership is an effort to increase the ability to create, formulate, communicate or socialize or transform, and implement ideal thoughts that come from him or as a result of social interaction between members of the organization and stakeholders is believed to be the future organizational ideals that must be achieved or realized through the commitment of all personnel.

In addition, the process and results of quality education are interrelated. Mulyasa stated the criteria for good quality education schools are expected to have several indicators that indicate that the school can be said to be of good quality. The indicator is the school environment. which is safe and orderly, the school has quality goals and targets to be achieved, the school has strong leadership, there is a continuous development of school staff in accordance with the demands of science and technology, and there is continuous implementation of evaluation of various academic and administrative aspects and the use of the results for improvement or improving the quality of education ${ }^{15}$.

Likewise, the meaning of quality in Islamic religious education is just that there is a minor addition, namely how schools or madrasas can balance the process and results of education so that students (graduates) become qualified Muslim humans. In a sense, students are able to develop a view of life, life attitudes and life skills with an Islamic perspective. Quality human understanding in the realm of Islamic thought is often referred to as a 'Kamil' person who has characteristics, including human beings who are in harmony (physical and spiritual, worldly and 'ukhrawi'), moralists (as individuals and socially), 'nazhar' and 'i'tibar' (critical, be 'ijtihad', dynamic, scientific attitude and forward-looking), and become a human being who prosper the earth 16 .

Improving the quality of education is inseparable from the existence of several factors, as follows: 1) clarity of educational goals in schools, 2) knowledge of students, 3) knowledge of teachers, 4) knowledge of supervision activities, 5) knowledge of teaching and 6) the ability to calculate time ${ }^{17}$.

The method used in this research is descriptive qualitative research, Bogdan and Taylor ${ }^{18}$, this type of research is also based on Sukardi's statement, which states that qualitative research seeks to describe research activities carried out on particular objects clearly and systematically ${ }^{19}$. So that the definition of qualitative research is a research procedure that produces descriptive data in the form of

14 Surdarman Danim, Visi Baru Manajemen Sekolah dari Unit Birokrasi ke Lembaga Akademik, (Jakarta, $3^{\text {rd }}$ ed, 2008), p. 219.

15 Mulyasa, Menjadi Kepala Sekolah yang Professional (Bandung: PT. Rosda Karya, 2005), p. 85.

16 Muhaimin, Pengembangan Kurikulum Pendidikan Agama Islam. (Jakarta: PT. Raja Grafindo Persada, 2005), p. 201

17 Moh. Rifai MA, Administrasi dan Supervisi Pendidikan (Bandung: Jemarss, 1982), Jilid II, p. 85.

${ }^{18}$ Lexy J. Moleong. Metodologi Penelitian Kualitatif (Bandung: Penerbit PT Remaja Rosdakarya. Offset, 2007) p. 4.

${ }^{19}$ Sukardi, Metodologi Penelitian Pendidikan Kompetensi dan Praktiknya, (Jakarta: Bumi Aksara, 2005), p. 14 
written or spoken words from people and observable behaviour, this approach is directed towards the individual's background holistically.

In this research, the author uses a phenomenological approach. The phenomenological approach aims to comprehend, investigate, and explain the nature and events and relationships with ordinary people in specific circumstances. It is generally referred to as qualitative study because it is focused on observational observations of natural social phenomena or symptoms ${ }^{20}$. The approach to the principal as a leader in educational institutions is taken in this research.

Interviewing and documentation are the methods used to collect data. The data was then edited, organized, and analyzed, with the principal of Madrasah Ibtidaiyah Al-Abrar Makassar being the main subject of the research informants.

\section{MADRASAH IBTIDAIYAH AL-ABRAR MAKASSAR}

Madrasah Ibtidaiyah Al-Abrar Makassar was founded in 1964. This Madrasah is under the auspices of the Al-Abrar Education Foundation. The pioneering figure for its founding was Ir. H. Ismail Bonro. He later became the head of the first Madrasah to lay the foundation for the development and development of education at the Al-Abrar Islamic Madrasah. Along with its development, Madrasah Ibtidaiyah Al-Abrar Makassar City has changed leadership seven times.

Madrasah Ibtidaiyah Al-Abrar is located in Mannuruki Village, Tamalate District, Jalan Sultan Alauddin No. 84 City of Makassar. The location of this school is quite strategic on the side of the highway. In recent years, through the leadership of existing school principals, they have begun to improve teacher professionalism. This indication arises from the success of Madrasah Ibtidaiyah (MI) Al-Abrar, winning achievements or awards when participating in various activities/competitions at the level of Makassar City, South Sulawesi Province as well as participation at the national level. In addition, several teachers have achievements in their fields and increase interest from teachers to further improve their professionalism. For example, the desire to improve education (those who have not yet continued S1, some have continued their Master's studies) includes training, training, and seminars. Moreover, deepen quality textbooks/science. More than that, Madrasah Ibtidaiyah Al-Abrar Makassar City and its foundation can maintain its institutional identity as a model educational institution and become a benchmark for quality management of education in Makassar City.

Visionary leaders are leaders who have a clear vision and mission in the organization. Visionary leaders are knowledgeable in observing future events and can clearly describe their vision and mission. It is consistent with the findings of interviews with the Head of Madrasah Ibtidaiyah Al-Abrar Makassar City. He confirmed that:

Translation: Madrasah Ibtidaiyah Al-Abrar must grow as a Madrasah that is superior in 'Imtaq' and Science and Technology, which is based on 'akhlakul karimah' that can produce a quality generation of Muslims so that it can contribute to the nation and country. Madrasahs must develop potential learning support facilities and provide teachers with academic, 
rational, and professional qualifications necessary for the mechanisms to achieve adequate learning outcomes in order to achieve this. These tasks are critical in the future for the Madrasah Ibtidaiyah Al-Abrar Makassar City to become a model for other ibtidaiyah madrasah in Makassar City ${ }^{21}$.

The results of the interview excerpt reflect the future insight of the head of Madrasah Ibtidaiyah Al-Abrar Makassar City, who views the importance of being the Madrasahs he leads. As a superior Madrasa and an example. In this regard, the Chairman of the Al-Abrar Foundation also admits that the head of the madrasa has insights that enable him to carry out his responsibilities from an individual perspective.

Translation: The principal of Madrasah Ibtidaiyah Al-Abrar, according to my observation, has hopes in developing this Madrasah in the future. Therefore, as the head of the foundation, I entrust the head of Madrasah Ibtidaiyah Al-Abrar to develop Madrasas according to his vision and mission and the applicable curriculum ${ }^{22}$.

Based on the result of the interview with the Head of Madrasah Ibtidaiyah AlAbrar in Makassar City, he has an insight into the potential growth of Madrasah Ibtidaiyah Al-Abrar as a Madrasah that is superior in the fields of 'Imtaq' and Science and Technology based on 'akhlakul karimah' based on the results of the interview. This necessitates an efficient Madrasah principal policy to promote the attainment of idealized ideas.

The head of the Madrasah Ibtidaiyah Al-Abrar Makassar City can formulate a clear vision of the Madrasah. The formulation of a vision is based on the formulated vision of Madrasah itself. The vision of Madrasah as stated in the following.

Translation: To excel in IMTAQ and science and technology based on gender-responsive noble character ${ }^{23}$.

This vision then becomes a reference for the head of the madrasah in formulating his vision. He stated as cited in the following quotation.

Translation: The vision I formulated is in line with the vision of the madrasah I lead. The description departs from this vision so that developing the quality of education to be achieved is directed. Therefore, Madrasah Ibtidaiyah Al-Abrar as a madrasah that excels in the fields of 'Imtaq' and Science and Technology is based on good morals. It applies to the potential of students and teachers in MI Al-Abrar Makassar." The foundation of the existing vision then becomes the planning framework for the Madrasah Ibtidaiyah Al-Abrar Madrasah program in Makassar City2.

${ }^{21}$ Andi Harmiah Tannang, The Head of MI Al-Abrar Makassar, interview, office, March $21^{\text {st }}$, 2017

${ }^{22}$ Andi Zainuddin Baso, The Head of Al-Abrar Makassar Foundation, interview, office, March $22^{\text {nd }}, 2017$

${ }^{23}$ Profil Madrasah Ibtidaiyah Al-Abrar Kota Makassar, 2017

${ }^{24}$ Andi Harmiah Tannang, loc.cit., 
Some Madrasah Ibtidaiyah Al-Abrar teachers also expressed their views when the author interviewed how the teacher responded to the vision of the head of the Madrasah.

Translation: It is perfect because, in the future, Madrasah Ibtidaiyah AlAbrar will produce students who excel in faith and piety, have knowledge and technology along with the noble character." "In my opinion, this vision is excellent because it can produce smart students who are competitive by prioritizing good morals so that it can reflect Madrasah Ibtidaiyah Al-Abrar as a quality madrasah ${ }^{25}$.

Based on the discussion of the interview results, it can be concluded that the head of Madrasah Ibtidaiyah Al-Abrar Kota Makassar can formulate a vision that has received positive responses from the Foundation and the teachers in the Madrasas it leads. The vision, as previously described, is a moral imagination that describes the desired school profile in the future. Such future imaginations will permanently be coloured by opportunities and challenges that are believed to occur in the future.

The leadership of the head of Madrasah Ibtidaiyah Al-Abrar Makassar City is said to be effective if it is able to raise the quality of education. The effectiveness of the head of the madrasa in developing the quality of education at Madrasah Ibtidaiyah Al-Abrar, Makassar City, can be seen to achieve standard processes, standards for educators and education personnel standards of facilities and infrastructure, standards of management.

In this regard, the Madrasah's head is trying to reach the optimum process standard possible.

Translation: At Madrasah Ibtidaiyah Al-Abrar, the standard procedure is being implemented successfully. Before beginning to teach, every teacher is required to plan lessons and prepare learning materials that will be used to ensure that the Madrasah runs smoothly, which is overseen by the Madrasah's head through monitoring, supervision, and assessment ${ }^{26}$.

The learning process Madrasah Ibtidaiyah Al-Abrar is running well because adequate facilities support it. The chairman of the Al-Abrar Foundation also stated that:

Translation: The most important thing is the aspect of the teacher that determines the achievement of the process standard because the matter of this process standard is entirely related to the teacher, starting from lesson planning, learning implementation, and evaluation. Foundations usually have little to do with their supervisory standards to ensure they are running at their best ${ }^{27}$.

${ }^{25}$ Sirajuddin, The Class Teacher of MI Al-Abrar Makassar, interview, office, March 23rd, 2017

${ }^{26}$ Andi Harmiah Tannang, loc.cit

${ }^{27}$ Andi Zainuddin Baso, The Head of Al-Abrar Makassar Foundation, interview, office, March 
The results of interviews and observations of educational qualifications at Madrasah Ibtidaiyah Al-Abrar in Makassar City meet the standards because, at the time of recruitment, Madrasahs applies a teacher recruitment mechanism under the standards set by the government. It is shown in an excerpt from an interview with

Madrasah Ibtidaiyah Al-Abrar. Educational applicants must apply to the Madrasah by referencing some of the minimum educational standards of S1 / diploma IV in the field of education. After that, educational candidates attend teaching orientation for two weeks. Educational candidates must have IT skills, arts, and have polite skills.

Translation: The standard of education personnel in Madrasah Ibtidaiyah Al-Abrar, Makassar City, has met the standards of education personnel because they have an average educational background of Strata Satu (S1). I, myself as the head of the Madrasah, have completed my Masters (S2) study28.

Every education unit is required to have infrastructures such as land, classrooms, an education unit leadership room, educators room, administration room, library room, laboratory room, workshop room, unit room, development, canteen, power and service installations, a place for sports, a place of worship, a place to play, a place to produce, and other spaces/places needed to support an orderly and sustainable learning environment.

The results of interviews and observations indicate that the facilities and infrastructure of Madrasah Ibtidaiyah Al-Abrar Makassar City are adequate. Educational support facilities and infrastructure at this madrasah are adequate. However, it still needs to be maintained and increased in capacity.

Translation: I began to make various efforts to increase the availability of facilities by collaborating with publisher partners to provide quality learning book facilities. In addition, cooperation is also carried out with campus institutions such as UIN Alauddin, Unismuh, and UNM. The preparation of infrastructure is also supported by the school committee's involvement and the government's distribution of efforts to use BOS and the Internet ${ }^{29}$.

In terms of infrastructure, the Chairman of the Al-Abrar Foundation is also optimistic about the numerous efforts made by the headmaster management of academic units on the ladder. Primary and secondary education implements school-based management is demonstrated by independence, partnership, participation, openness and accountability.

Translation: The management of education at Madrasah Ibtidaiyah AlAbrar applies school-based management so that independence, partnerships with teachers, foundations, and committees, openness and

${ }^{28}$ Andi Harmiah Tannang, loc.cit

${ }^{29}$ Andi Zainuddin Baso, loc.cit 
accountability must be realized to develop the quality of learning. All elements of school-based management are running well ${ }^{30}$.

Based on this explanation, the education management requirements implemented by Madrasah principals complied with Article 49 concerning the management of education units at the primary and secondary levels, which must incorporate school-based management characterized by freedom, partnership, engagement, transparency, and accountability.

\section{Closing}

Based on the research and discussion results described in the previous chapter, the following conclusions can be summarized. The visionary leadership strategy of the headmaster of Madrasah in developing the quality of education at Madrasah Ibtidaiyah Al-Abrar in Makassar City includes: the vision that was initiated seems to be looking to the future. Capable of forming a coherent vision, as shown by the vision elaboration, which relates to the madrasah vision that has been formulated. Capable of transforming vision into reality, as demonstrated by the mission formulation and the principal of the Madrasah's exemplary performance. Dare to act to achieve goals such as resolving conflicts, disciplining all employees, teachers, and students, and making breakthroughs. Capable of mobilizing others, as shown by the head of the Madrasah's participation in coordinating teachers and Madrasah committees. He builds effective relationships with all madrasah management elements, as evidenced by coordination, inspiration, and accountability. Holding fast to spiritual principles, it appears in his opinion that he should carry out his duties under the Qur'an and its behavior, innovative and proactive appearances in the improvement and arrangement of Madrasah infrastructure and reforms made in the learning aspect and finding solutions to various problems.

The following lists demonstrate the effectiveness of the head visioner's leadership in improving the quality of education at Madrasah Ibtidaiyah Al-Abrar Makassar City: implementation of process standards is achieved. Standards of educators and education personnel are achieved. Standards of facilities and infrastructure are adequate and management standards are running well and transparently.

${ }^{30}$ Andi Harmiah Tannang, loc.cit 


\section{BIBLIOGRAPHY}

Aan Komariah dan Cepi Triatna, Visionary Leadership Menuju Sekolah Efektif, (Jakarta: Bumi Aksara, 2005.

Ahmad Tafsir, Ilmu Pendidikan Islam dalam Prespektif Isalam Bandung: PT. Remaja Rosdakarya, 1991.

Departemen Agama Republik Indonesia, Al Qur'an dan Terjemahannya, Semarang: PT Toha Putra, 1998.

Depdiknas, Panduan Manajemen Pendidikan, Jakarta: 2000.

Gene E, Lindah F, Donna M, Mengajar Dengan Menyenangkan, Jakarta: Indeks, 2008.

Lexy J. Moleong. Metodologi Penelitian Kualitatif, Bandung: Penerbit PT Remaja Rosdakarya. Offset, 2007.

M. Quraish Shihab, Tafsir Al-Mishbah; Pesan, Kesan Dan Keserasian Al-Qur'an, (Jakarta: Lentera Hati, 2002.

Moh. Rifai MA, Administrasi dan Supervisi Pendidikan (Bandung: Jemarss, 1982), Jilid II,

Muhaimin, Pengembangan Kurikulum Pendidikan Agama Islam. (Jakarta: PT. Raja Grafindo Persada, 2005.

Mulyasa, Menjadi Kepala Sekolah yang Professional Bandung: PT. Rosda Karya, 2005.

Nur Ahmad, "Problem Pengelolah Madrasah Aliyah dan Solusinya," Islamica, Vol. 18, No. 2 March 2010.

Rasmianto, "Kepemimpinan Kepala Sekolah Berwawasan Visioner-Tranformatif", eLHarakah, No. 59, (Malang: UIN Malang, 2003.

Rasmianto, "Kepemimpinan Kepala Sekolah Berwawasan Visioner-Tranformatif", Pendidikan dan Kebudayaan, eL-Harakah, No. 59 Malang: UIN Malang, March-June 2003.

Sudarwan Danim, Visi Baru Manajemen Sekolah Dari Unit Birokrasi ke Lembaga Akademik, Jakarta: Bumi Aksara, 2008.

Sukardi, Metodologi Penelitian Pendidikan Kompetensi dan Praktiknya, Jakarta: Bumi Aksara, 2005.

Suparji, "Profesionalime Guru. "Jurnal Pendidikan dan Kebudayaan, Edukasi, No.14 Sumenep: Dispen, 2010.

Surdarman Danim, Visi Baru Manajemen Sekolah dari Unit Birokrasi ke Lembaga Akademik, Jakarta, ed. III, 2008. 